\title{
PENGARUH PENGGUNAAN ZEOLIT ALAM SEBAGAI FILLER PADA CAMPURAN AC-BC DITINJAU DARI NILAI VITM
}

\author{
Alfian Saleh \\ Program Studi Teknik Sipil Universitas Lancang Kuning \\ Jalan Yos Sudarso Km. 8 Rumbai Pekanbaru \\ E-mail : alfian.saleh@unilak.ac.id
}

\begin{abstract}
Abstrak
Indonesia memiliki kekayaan sumber alam yang tinggi, termasuk sumber mineral yang menjadi bahan baku perkerasan jalan. Pemanfaatan sumber alam berupa bahan baku perkerasan jalan masih belum banyak dikembangkan, terlebih kaitannya untuk mengatasi permasalahan kerusakan dini pada perkerasan jalan. Aspal Pen. 60/70 dan zeolit alam merupakan salah satu kekayaan alam yang bisa digunakan, namun penelitian terkait kedua bahan tersebut masih belum banyak dilakukan. Penggabungan kedua bahan dalam pengujian dilakukan dengan perancangan benda uji menggunakan 5 variasi kadar filler, yaitu variasi 1 (100\% debu batu : 0\% zeolit alam), variasi 2 (75\% debu batu : 25\% zeolit alam), variasi 3 (50\% debu batu : $50 \%$ zeolit alam), variasi 4 (25\% debu batu : 75\% zeolit alam) dan variasi 5 (0\% debu batu : $100 \%$ zeolit alam). Kemudian dari nilai KAO yang didapat dilakukan pengujian Marshall untuk mendapatkan nilai VITM. Dan didapat hasil bahwa semakin tinggi kadar aspal, maka nilai VITM akan semakin menurun. Artinya semakin tinggi kadar aspal, maka rongga dalam campuran akan berkurang. Hal ini terjadi karena penambahan aspal membuat rongga udara yang ada semakin berkurang karena terisi oleh aspal.
\end{abstract}

Kata Kunci : $\quad$ Aspal Pen.60/70, Marshall, Nilai VITM, Zeolit Alam

\begin{abstract}
Indonesia has a wealth of natural resources is high, including mineral resources into pavement materials. Utilization of natural resources such as raw materials pavement still has not been developed, especially to overcome the problems related to premature pavement damage. Asphalt Pen. 60/70 and natural zeolite is a natural asset that can be used, but the study linked the two materials are still not widely practiced.Merging the two materials in the testing done with the design of the test specimen using 5 filler content variation, the variation of 1 (100\% stone dust: $0 \%$ natural zeolite), variation 2 (75\% stone dust: $25 \%$ natural zeolite), variation 3 (50\% stone dust: $50 \%$ natural zeolite), variations 4 (25\% stone dust: $75 \%$ natural zeolite) and variation 5 (0\% stone dust: $100 \%$ natural zeolite). Then from the value obtained KAO Marshall testing to obtain VITM value. And the results obtained that the higher bitumen content, then the value of VITM will decrease. This means that the higher the bitumen content, the cavity in the mix will be reduced. This happens because the addition of asphalt to make the air cavity that there is increasingly reduced because filled by asphalt.
\end{abstract}

Keywords : Asphalt Pen.60/70, Marshall Test, VITM Value, Natural Zeolite 


\section{A. PENDAHULUAN}

Dalam bidang konstruksi perkerasan lentur jalan raya, kemampuan layan merupakan hal yang signifikan untuk diperhatikan. Salah satu penyebab utama dan memburuknya kemampuan layan adalah rendahnya daya tahan lapisan perkerasan dalam menerima beban lalu lintas berat yang sering dihubungkan dengan ketahanan deformasi permanen. Campuran aspal adalah campuran yang terdiri dari kombinasi agregat yang dicampur dengan aspal. Pencampuran dilakukan sedemikian rupa sehingga permukaan agregat terselimuti aspal dengan seragam. Untuk mengeringkan agregat dan mendapatkan kekentalan aspal yang mencukup dalam mencampur dan mengerjakannya, maka kedua-duanya harus dipanaskan masing-masing pada suhu tertentu (Manual Pengerjaan Campuran Beraspal Panas, 2004). Agregat yang umum digunakan untuk perkerasan jalan adalah batu pecah, pasir dan memiliki persentase yang paling kecil dibandingkan dengan agregat kasar dan halus, namun filler mempunyai pengaruh yang signifikan pada campuran perkerasan jalan raya, karena filler mengisi rongga udara pada campuran perkerasan jalan raya. Serta aspal sebagai bahan ikat secara umum di Indonesia menggunakan aspal pertamina.

Indonesia sebagai salah satu negara kepulauan dengan cadangan zeolit alam terbesar di dunia dan tersebar hampir di setiap daerah, terutama di Pulau Jawa (Distamben Jabar, 2002 dan Sugih, 2008), dengan jumlah deposit alam sekitar 400 juta ton. Berdasarkan alasan tersebut di atas, perlu adanya penelitian membuat campuran aspal dengan zeolit alam sebagai bahan pengganti.

\section{B. TINJAUAN PUSTAKA}

\section{Perkerasan Jalan}

Menurut Suparma (2002), perkerasan jalan adalah lapisan tambahan yang berada di antara beban lalulintas dengan tanah dasar yang bersifat konstruktif, sehingga memiliki nilai struktural dan fungsional. Nilai struktural dari perkerasan jalan adalah sebagai penerima, penerus dan penyebar beban kendaraan ke lapis di bawahnya, baik beban vertikal maupun beban horizontal. Nilai fungsional dari perkerasan jalan adalah memberikan kenyamanan dengan menyediakan permukaan yang rata dan sebagai lapis kedap air.

\section{Beton Aspal (Asphalt Concrete- AC)}

Beton Aspal adalah jenis perkerasan jalan yang terdiri dari campuran agregat dan aspal, dengan atau tanpa bahan tambah. Faktor-faktor yang menentukan daya tahan perkerasan yaitu sifat agregat, sifat aspal dan temperatur. Agregat digunakan sebagai kerangka dan aspal sebagai pengikat campuran. Temperatur adalah faktor utama dalam pemeriksaan yang akan menentukan temperatur pemadatan. Jika digunakan semen aspal, maka suhu pencampuran umumnya antara $145^{\circ} \mathrm{C}$ $155^{\circ} \mathrm{C}$, sehingga disebut aspal beton campuran panas. Campuran ini dikenal dengan nama Hotmix (Asphalt Institute, 2001).

\section{Bahan Campuran Beton Aspal}

a. Agregat

Agregat adalah suatu kombinasi dari pasir, kerikil, batu pecah atau 
kombinasi material lain yang digunakan dalam campuran beton aspal. Proporsi agregat kasar, agregat halus dan bahan pengisi (filler) didasarkan pada spesifikasi dan gradasi yang tersedia.

b. Filler

Filler atau biasa disebut bahan pengisi yaitu batuan lolos saringan No. $200(0,075 \mathrm{~mm})$. Filler adalah bahan pengisi rongga dalam campuran (void in the mix) yang berbutir halus. Fungsi filler pada perkerasan adalah untuk meningkatkan stabilitas dan mengurangi rongga udara dalam campuran, sehingga walaupun kecil filler memiliki kegunaan yang sangat besar sekali pengaruhnya. Filler dapat berupa debu batu kapur, debu dolomite, Semen Portland atau bahan non plastis lainnya. Bahan tersebut harus bebas dari kotoran, kering dan bahan lain yang tidak dikehendaki.

c. Aspal

Aspal terbuat dari minyak mentah, melalui proses penyulingan atau dapat ditemukan dalam kandungan alam sebagai bagian dari komponen alam yang ditemukan bersamasama material lain. Aspal dapat pula diartikan sebagai bahan pengikat pada campuran beraspal yang berbentuk dari senyawasenyawa kompleks seperti asphaltenese, resins dan oils. Aspal mempunyai sifat visco-elastis dan tergantung dari waktu pembebanan. Pada proses pencampuran dan proses pemadatan sifat aspal dapat ditunjukkan dari nilai viskositas. Sifat viskositas yang diwujudkan dalam suatu nilai modulus kekakuan (Bitumen S., 1990).

\section{Zeolit sebagai Filler dalam Campuran Aspal dan Agregat}

Zeolit merupakan salah satu kekayaan alam yang sangat bermanfaat bagi industri kimia di Indonesia. Zeolit ada dua macam yaitu zeolit alam dan sintetik. Zeolit alam sudah banyak dimanfaatkan, umumnya zeolit alam digunakan untuk pupuk, penjernihan air, dan diaktifkan untuk dimanfaatkan sebagai katalis dan adsorbent (Furqon A., dan Hendri H., 2011).

\section{Void In The Mix (VITM)}

Void In The Mix (VITM) adalah persentase rongga yang terdapat dalam total campuran. Nilai VITM berpengaruh terhadap keawetan lapis perkerasan, semakin tinggi nilai VITM menunjukkan semakin besar rongga dalam campuran sehingga campuran bersifat porus. Hal ini mengakibatkan campuran menjadi kurang rapat sehingga air dan udara mudah memasuki rongga-rongga dalam campuran yang menyebabkan aspal mudah teroksidasi sehingga menyebabkan lekatan antar butiran agregat berkurang sehingga terjadi pelepasan butiran (reveling) dan pengelupasan permukaan (stripping) pada lapis perkerasan.

\section{DATA DAN ANALISA DATA}

\section{Tempat dan Waktu Penelitian}

Lokasi penelitian dilakukan di Laboratorium Jalan Raya yang sudah berstandar SNI dan penelitian dilakukan secara eksperimental kausal baik saat pengambilan data ataupun menganalisis data. Jenis penelitian ini dapat diartikan sebagai sebuah studi yang objektif, sistematis dan terkontrol untuk memprediksi hasil akhir dari hasil penelitian. Penelitian eksperimental 
kausal bertujuan untuk menyelidiki hubungan sebab akibat (cause and effect relationship) yaitu mempersoalkan adanya variabel bebas dan tidak bebas. Variabel bebas yang dimaksudkan adalah persentase volume zeolit sedangkan variabel tidak bebas adalah karakteristik spesifikasi Marshall yang sudah ditentukan. Hasilnya dibandingkan dan dipaparkan dalam bentuk suatu penulisan dilengkapi dengan data-data hasil pengujian.

\section{Bahan dan Alat Penelitian}

Penelitian dilakukan di laboratorium sehingga memerlukan alatalat di Laboratorium khusunya alat untuk menentukan properties aspal. Adapun alat penelitian yang digunakan sebagai berikut:

a. Penetrasi pada suhu $25^{\circ} \mathrm{C}(0,1 \mathrm{~mm})$ : SNI 06-2456-1991

b. Viskositas $135^{\circ} \mathrm{C}$ (ceni Stokes)

: AASHTO T201-03

c. Titik lembek $\left({ }^{\circ} \mathrm{C}\right)$

: SNI 06-2434-1991

d. Daktilitas pada $25^{\circ} \mathrm{C},(\mathrm{cm})$

: SNI 06-2432-1991

e. Titik nyala $\left({ }^{\circ} \mathrm{C}\right)$

: SNI 06-2433-1991

f. Kelarutan dalam Trichloroethylene (\%) : AASHTO T44-03

g. Berat jenis (gr/cc)

: SNI 06-2442-1991

h. Stabilitas penyimpanan $\left({ }^{\circ} \mathrm{C}\right)$

: ASTM D5976 part 6.1

i. Keelastisan setelah pengembalian $\left({ }^{\circ} \mathrm{C}\right)$ : ASTM T301-98

\section{Prosedur Penelitian}

Penelitian dilakukan dengan cara mengambil data pengujian dari laboratorium yang berupa : a. Tahapan input yang dilakukan pada tahap ini, antara lain: pengumpulan data sekunder

b. Tahapan proses yang dilakukan pada tahap ini, antara lain: melakukan kegiatan merancang campuran rencana dengan berbagai macam variasi kadar filler yang digunakan yaitu variasi $1 \quad(100 \%$ debu batu+0\% zeolit alam), variasi $2 \quad(75 \%$ debu batu $+25 \%$ zeolit alam), variasi $3 \quad(50 \%$ debu batu+50\% zeolit alam), variasi 4 ( $25 \%$ debu batu $+75 \%$ zeolit alam) dan variasi 5 ( $0 \%$ debu batu+100\% zeolit alam), pengujian dengan standar yang ada dan melakukan analisis dengan membandingkan data pengujian dengan standar spesifikasi

c. Tahapan output yang dilakukan pada tahap ini, antara lain: memberikan kesimpulan, saran dari penelitian yang dilakukan dan memberikan rekomendasi terhadap penggunaan zeolit alam sebagai filler.

Data-data yang didapat akan dianalisis menjadi sebuah kesimpulan mengenai pengaruh variasi penggunaan zeolit dan kadar aspal Terhadap VITM (Void In the Mix).

\section{Analisis Data}

Secara umum analisis data dapat diuraikan sebagai berikut : melakukan analisis terhadap sifat-sifat fisik aspal, apabila telah memenuhi spesifikasi Bina Marga dilakjutkan dengan mencari Kadar Aspal Optimum dengan menggunakan rumus $\mathrm{Pb}=0,035 \mathrm{~F} 1+$ $0,045 \mathrm{~F} 2+0,18 \mathrm{~F} 3+\mathrm{K}$; kemudian melakukan variasi persentase filler debu batu dan zeolit yaitu $100 \%$ debu batu, $75 \%$ debu batu+25\% zeolit, $50 \%$ debu batu $+50 \%$ zeolit, $25 \%$ debu batu $+75 \%$ zeolit dan $100 \%$ zeolit. Kemudian 
dengan setiap variasi didapat Kadar Aspal Optimum (KAO) dan setiap variasi dengan kadar aspal optimum yang didapat dilakukan pengujian Marshall yang terfokuskan pada nilai VITM.

\section{HASIL DAN PEMBAHASAN}

\section{Data Hasil Pemeriksaan Aspal Pen.60/70}

Dari hasil pengujian laboratorium yang didapat dari hasil pemeriksaan aspal Pen.60/70 pada Tabel 1. Dari hasil pengujian bahan-bahan menunjukkan bahwa bahan-bahan yang akan digunakan dalam penelitian ini telah memenuhi persyaratan sebagai bahan perkerasan.

\section{Data Hasil Pemeriksaa Agregat Kasar, Agregat Halus, Debu Batu dan Zeolit}

Hasil pemeriksaan agregat kasar, agregat halus,debu batu dan zeolit dapat dilihat pada Tabel 2 .

Tabel 1. Persyaratan dan Hasil Pemeriksaan AC 60-70

\begin{tabular}{lcccc}
\hline \multicolumn{1}{c}{ Jenis Pemeriksaan } & \multicolumn{2}{c}{ Syarat } & Hasil & Satuan \\
\hline atau Pengujian & Min & Max & & \\
\hline Penetrasi & 60 & 79 & 62,2 & $0,1 \mathrm{~mm}$ \\
Titik lembek & $48^{\circ} \mathrm{C}$ & $58^{\circ} \mathrm{C}$ & 50 & ${ }^{\circ} \mathrm{C}$ \\
Titik nyala & $200^{\circ} \mathrm{C}$ & - & 330 & ${ }^{\circ} \mathrm{C}$ \\
Kelarutan TCE & $99 \%$ berat & - & 99 & $\%$ berat \\
Daktilitas & $100 \mathrm{~cm}$ & - & 165 & $\mathrm{Cm}$ \\
Berat jenis & 1 & - & 1,01 & - \\
\hline
\end{tabular}

Tabel 2. Hasil Pemeriksaan Agregat dan Filler

\begin{tabular}{|c|c|c|c|c|}
\hline No. & Jenis Pemeriksaan & Satuan & Spesifikasi *) & Hasil \\
\hline \multicolumn{5}{|c|}{ Agregat Kasar } \\
\hline 1 & Keausan dengan mesin Los Angeles & $\%$ & $<40$ & 26,9 \\
\hline 2 & Penyerapan Air & $\mathrm{gr} / \mathrm{cm}^{3}$ & $<3$ & 1,055 \\
\hline 3 & Berat Jenis Semu & $\mathrm{gr} / \mathrm{cm}^{3}$ & $>2,50$ & 2,653 \\
\hline 4 & Berat Jenis Kering (Bulk) & $\%$ & $>2,50$ & 2,581 \\
\hline 5 & Soundness Test & $\%$ & $<12$ & 0,082 \\
\hline 6 & Partikel Pipih dan Lonjong & $\%$ & $>10$ & 2,14 \\
\hline 7 & Material Lolos Ayakan No. 200 & $\%$ & $<1$ & 0,33 \\
\hline \multicolumn{5}{|c|}{ Agregat Halus } \\
\hline 1 & Sand Equvalent & $\%$ & $>60$ & 75,00 \\
\hline 2 & Penyerapan Air & $\%$ & & 1,087 \\
\hline 3 & Berat Jenis Semu & $\mathrm{gr} / \mathrm{cm}^{3}$ & $>2,50$ & 2,623 \\
\hline 4 & Berat Jenis Kering (Bulk) & $\mathrm{gr} / \mathrm{cm}^{3}$ & $>2,50$ & 2,550 \\
\hline 5 & Material Lolos Ayakan No. 200 & $\%$ & $<8$ & 0,48 \\
\hline \multicolumn{5}{|c|}{ Filler } \\
\hline 1 & Berat Jenis Semu Debu Batu & $\mathrm{gr} / \mathrm{cm}^{3}$ & $>2,50$ & 2,61 \\
\hline 2 & Berat Jenis Semu Zeolit Alam & $\mathrm{gr} / \mathrm{cm}^{3}$ & - & 2,19 \\
\hline
\end{tabular}

*) Sumber : Spesifikasi Umum 2010 Revisi II (2012) 


\section{Hasil Pengujian Perkerasan Aspal dengan Marshall yang Dtinjau dari Nilai VITM}

VITM (Void In the Mix) adalah persentase rongga udara yang ada dalam suatu campuran. Nilai VITM akan berkurang apabila kadar aspal campuran bertambah, karena rongga agregat akan semakin terisi oleh aspal. Besarnya VITM dipengaruhi oleh suhu pemadatan, gradasi agregat, energi pemadatan, energi aspal dan jumlah tumbukan dalam pemadatan. Nilai VITM dapat menggambarkan tingkat kekedapan suatu campuran. Semakin besar nilai VITM maka semakin besar pula rongga yang dimiliki suatu campuran. Apabila kadar rongga dalam suatu campuran besar, maka akan membuat campuran tersebut semakin kurang kedap. Kondisi campuran yang dimiliki kekedapan yang kurang akan membuat air itu lebih mudah meresap dan masuk kedalam campuran. Sebaliknya, bila suatu campuran memiliki VITM yang terlalu rendah, maka campuran memiliki kekedapan yang tinggi sehingga akan terjadi bleeding. Hal tersebut terjadi karena temperatur perkerasan yang tinggi mengakibatkan aspal mencair namun tidak ada ruangan yang cukup untuk campuran. Gambar 1 yang menunjukkan hubungan antara VITM dengan variasi kadar aspal.

Berdasarkan grafik yang ditunjukkan Gambar 1 dapat diketahui bahwa semakin tinggi kadar aspal, maka nilai VITM akan semakin menurun. Artinya semakin tinggi kadar aspal, maka rongga dalam campuran akan berkurang. Hal ini terjadi karena penambahan aspal membuat rongga udara yang ada semakin berkurang karena terisi oleh aspal. Pada Gambar 1 menunjukkan bahwa pada variasi 5 (0\% debu batu dan 100\% zeolit) dengan kadar aspal paling kecil yaitu 5\% memiliki VITM paling besar. Perbedaan nilai VITM ini disebabkan oleh adanya perbedaan berat jenis yang dimiliki oleh debu batu dan zeolit alam.

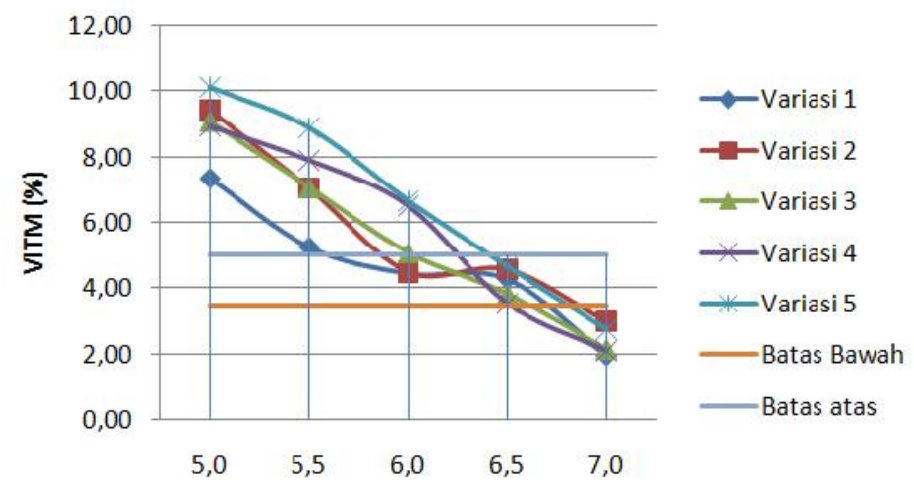

Gambar 1. Hubungan antara VITM dengan Variasi Filler dan Kadar Aspal

\section{E. KESIMPULAN}

Dari hasil pembahasan dan tujuan dari penelitian ini dapat disimpulkan sebagai berikut:

1. Agregat yang digunakan dalam penelitian mempunyai mutu yang sesuai dengan spesifikasi umum
Kementerian Pekerjaan Umum 2010 Revisi II (2012).

2. Aspal yang digunakan dalam penelitian mempunyai mutu yang sesuai dengan spesifikasi umum Kementerian Pekerjaan Umum 2010 Revisi II (2012) 
3. Dari nilai VITM yang didapat bahwa semakin tinggi kadar aspal, maka nilai VITM akan semakin menurun. Artinya semakin tinggi kadar aspal, maka rongga dalam campuran akan berkurang. Hal ini terjadi karena penambahan aspal membuat rongga udara yang ada semakin berkurang karena terisi oleh aspal.

\section{DAFTAR PUSTAKA}

AASHTO, 1993, Sampling Bituminous

Paving Mixtures, AASHTO

Designation $\mathrm{T}$ 168-82, Part II

Test, $16^{\text {th }}$ Edition.

Annual Book of ASTM Standart, 1989, American Society For Testing

Material, Philadelphia.

Asphalt Institute, 2001, Construction of

Hot Mix Asphalt Pavement, MS-

22, Six Edition, Lexington, Kentucky, USA.

ASTM, 1997, Road and Paving

Materials Vehicle - Pavement

System, Published By The

American Society of Testing

Material Officials, Washington

D.C

Atkins HN., 1997, Highway Materials,

Soils and Concretes, $3^{\text {th }}$ Edition

Prentice Hall, New Jersey.

Departemen Pekerjaan Umum, 2010

(Revisi II), Spesifikasi Umum

Bidang Jalan dan Jembatan,

Badan Penelitian dan

Pengembangan PU, Departemen

Pekerjaan Umum, Jakarta.
Furqon A., 2011, Pengaruh Metode Aktivasi Zeolit Alam Sebagai

Bahan Penurun Temperatur Campuran Beraspal Hangat, Pusat Litbang Jalan dan Jembatan, Bandung.

Laboratorium Teknik Transportasi, 2013, Modul Praktikum Bahan

Perkerasan Jalan, Jurusan

Teknik Sipil, Fakultas Teknik

Sipil dan Lingkungan Universitas

Gadjah Mada, Yogyakarta.

Sastra M., 2013, Perancangan

Laboratorium Pada Campuran

Asphaltic Concrete Binder

Course (AC-BC) Dengan Abu

Serbuk Bungkil Biji Pohon Jarak

Pagar Sebagai Filler, Tesis

MSTT, Universitas Gadjah Mada, Yogyakarta.

Bitumen S., 1990, The Shell Bitumen Hand Book, Published By Shell

Bitumen, East Molesey Serrey.

Suparma LB., 2011, Bahan Konstruksi

Perkerasan, Buku Materi Kuliah

MSTT, Universitas Gadjah Mada,

Yogyakarta.

The Asphalt Institute, 1983,

Construction of Hot Mix Asphalt

Pavement, Manual Series No. 22,

Second Edition, Lexington,

Kentucky, USA.

The Asphalt Institute, 1993, Mix Design

Methods for Asphalt Concrete and other Hot Mix Types, Manual Series No. 2 (MS-2), $5^{\text {th }}$ Edition, Lexington, Kentucky, USA. 